\title{
Истернизация русской повседневности: история и современность ${ }^{1}$
}

\author{
В.И. ИЛЬИН*
}

\begin{abstract}
*Владимир Иванович Ильин - доктор социологических наук, профессор, СанктПетербургский государственный университет; ассоциированный сотрудник, Социологический институт РАН. Адрес: 191124, Санкт-Петербург, ул. Смольного, д. 1/3. E-mail: ivi-2002@yandex.ru
\end{abstract}

Цитирование: Ильин В.И. (2019) Истернизация русской повседневности: история и современность // Мир России. Т. 28. № 2. С. 25-41. DOI: $10.17323 / 1811-038 X-2019-28-2-25-41$

Прочессы культурной диффузии как фактор развития русской повседневной культуры веками шли в форме вестернизации и истернизации, и почти на всех этапах русской истории, включая современный, доминировала вестернизаџия. При этом истернизация очень часто принимала парадоксальные формы вестернизации: 1) восточное влияние на русскую повседневную культуру часто оказывалось через западныле страны; 2) из стран Востока импортировались товары, изначально появившиеся в западной культуре, но производимые в дальнейшем в восточных государствах.

В отличие от вестернизачии истернизация повседневности обычно не влекла за собой изменений структур образа жизни. Причина состояла в том, что импортируемые элементы восточной культуры были глубоко укоренены в качестве элементов иельной системы ментальности, в то время как вестернизация повседневности опиралась на удовлетворении естественных универсальных потребностей в физическом и духовном комфорте, благодаря чему она легко прививалась к любой культуре, порождая своеобразные глокальнье гибриды.

Восток внедрялся в Россию в двух формах: с одной стороны, это было прямое проникновение в пространство русской повседневности (от нашествия агрессоров до импорта товаров); с другой, Восток регулярно проявлялся в виде мифа, и эти ипостаси частично переплетались (миф стимулировал импорт, выступая инструментом «мягкой силь»).

Целью данной статьи является концептуализация категории истернизации российской повседневности как сквозного процесса российской истории.

1 Исследование выполнено при поддержке Core University Program for Korean Studies through the Ministry of Edu-cation of the Republic of the Korea and Korean Studies Promotion Service of the Academy of Korean Studies (AKS-2016-OLU-2250002). 
Ключевые слова: американизация, глокализация, вестернизация, истернизация, ориентализм, повседневность, миф, идентичность

Глокализация русской повседневной культуры имеет два основных вектора - вестернизацию и истернизацию. Оба вектора уходят в глубины истории, оказывая существенное влияние на культурную динамику. Истернизация повседневности в отличие от вестернизации обычно не имеет серьезных последствий и сводится к интеграции в местный образ жизни новых элементов, не внося при этом качественных изменений.

\section{Феномен истернизации повседневности}

Культура эволюционирует двояким образом: с одной стороны, это саморазвитие через поиск путей разрешения возникающих противоречий, с другой, это культурная диффузия как процесс распространения и заимствования идей, стилей, религиозных убеждений, ритуалов, технологий, материальных объектов, языка и его элементов. Это проникновение начинается в далекой древности и продолжается до настоящего времени. С момента становления глобального капитализма четко прослеживаются два встречных вектора: один - с Запада на Восток, другой - в обратном направлении, и в современном мире эти потоки приняли форму глобализации. В последние столетия ее основной направляющей стала вестернизация, под которой понимается распространение и усвоение европейских идей, технологий, стилей жизни и институтов по всему миру. Однако из глубины веков идет и противоположный процесс культурного влияния - истернизация. Роль восточных стран как самостоятельного двигателя глобализации вполне очевидна, а процесс вестернизации, доминировавший в колониальную и постколониальную эпохи, многим кажется уже завершившимся [Mahbubani 2009]. С. Хантингтон утверждал, что после окончания холодной войны мировая политика начала меняться в сторону превращения незападных цивилизаций в активного творца мировой истории [Хантингтон 2003].

Категория истернизации (easternization) вошла в научный оборот в середине 1990-х гг. [Campbell 2007] и первоначально использовалась для описания, с одной стороны, восточного (преимущественно японского) менеджмента в западных странах (см. [Kaplinsky 1994]), а с другой, адаптации западных экономических практик к особенностям культуры в странах Дальнего Востока [Aw, Hwang 1995; Hwang, Mai 1995] По мере усиления роли азиатских стран в мировой экономике и политике этот термин был заимствован для анализа геополитических процессов. Как пишет аналитик Financial Times, «истернизация является определяющим трендом нашего века» [Rachman 2007].

В своей книге «Истернизация Запада» Колин Кемпбелл использовал понятие «истернизация» для анализа культурных трансформаций в западных странах (в основном, США). В центре его внимания оказались не ставшее уже привычным столкновение цивилизаций и не глобализация, схожая с вестернизацией, а культурные изменения самого Запада под влиянием отношений с Востоком. Он утверждал, что Запад перестал быть Западом, а Восток, все еще уступая Западу в области 
экономики и военной мощи, на протяжении всего XX в. (особенно начиная с 1960-х гг.) начал оказывать большее влияние на западную духовную жизнь [Campbell 2007]. Изменилось и отношение жителей западных стран к восточным культурам: они все чаще видели в них источник для обогащения собственных культур [Nair-Venugopal 2012]. Встречается это понятие (правда, без его концептуализации) и в исторической науке: например, в книге, посвященной истории Римской империи, под истернизацией понимается влияние на ее жизнь восточного эллинизма [Voegelin 1997], однако это совсем иной Восток. Истернизация вызывает ассоциации с категорией ориентализма, введенной в оборот в конце 1980-х гг. [Said 2014], но она обозначает не систему интерпретаций восточной культуры на Западе, а ее проникновение в разные сферы его жизни.

Заметным элементом процесса истернизации Запада стало увлечение дзенбуддизмом, приобретшего значимые масштабы в 1960-1970-е гг. и ставшего частью сначала контркультуры хиппи, а затем и практик достаточно широких кругов интеллектуалов и богемы [Bогир 2015]. Зарождение этого процесса уходит корнями во вторую половину XIX в., в эпоху популярности теософии и трансцендентализма. В настоящее время на волнах массовой миграции в страны Европейского союза пришел ислам как значимый фактор формирования культурного ландшафта.

Истернизация наряду с вестернизацией, выступая как одна из сторон медали глобализации, в условиях баланса двух противоположностей принимает форму глобальной культуры как сплава [Smith 1990], который точно передается с помощью категории глокализации, фокусирующей внимание на том, как глобальные процессы подвергаются локализации. Президент японской корпорации Sony A. Морита ввел в оборот этот термин для анализа стратегии продвижения на рынок какой-либо страны товаров и услуг, производимых в массовом масштабе в других регионах планеты. В 1990-е гг. Р. Робертсон превратил это понятие в важную научную категорию, позволяющую анализировать переплетение процессов глобализации и локализации [Robertson 1994; Бек 2011; Согомонов 2001].

Но что такое «Восток»? В русской общественной мысли начала 1920-х гг., в целом, и в трудах евразийцев, в частности, эта проблема приобрела особую актуальность. Н.С. Трубецкой, призывавший к освобождению России от гегемонии Запада, понимал «Восток» как сложный цивилизационный феномен: с одной стороны, это восточное христианство, с другой, Азия. При этом евразийцы, отделяя «внутренний Восток» от «внешнего», граница между которыми совпадала с границами СССР 1920-х гг., «внутренним Востоком» определяли Евразию (см. [Назмутдинов 2015, с. 132-133; Назмутдинов 2016, с. 118]).

«Восток», как отмечает Э.В. Саид, - это артефакт Запада или европейская идея Востока. В своей книге он использует два термина - East и Orient, первый употребляется в географическом смысле, а второй - в культурном. Аналогичным образом «Восток» присутствует и в русской повседневной культуре как очень размытое, мифологическое понятие, обозначающее широкий и противоречивый набор культур народов, которые не принадлежат ни к «Западу», ни к собственно русской культуре. По мнению Э. Саида, это «трафаретные представления толпы» [Caud 2003; Said 2014]. Следует уточнить, что в настоящей статье используется категория русской, а не российской повседневности, поскольку у каждого народа нашей страны свой путь истернизации: например, для исламских народов России истернизация имеет существенно иные смыслы. 
Таким образом, «Восток», как фактор влияния на повседневную культуру западных стран и России, выступает в двух ипостасях. С одной стороны, это «страны Азии, северо-восточной Африки и юго-восточной Европы, противопоставляемые странам с западноевропейской культурой» [Восток б/г], с помощью жесткой и/или «мягкой силы» влияющие на условия жизни в иной цивилизации. С другой, «Восток» - это миф, обладающий мощной притягательной силой и входящий в европейскую культуру именно в таком качестве. Как пишет Э. Саид, «Восток подвергается ориентализации» [Саид 2016, с. 106], и в этом качестве он используется для конструирования собственной идентичности через миф о другом мире - чуждом, экзотическом, опасном и непонятном. Этот «Восток» постоянно меняет свой облик, поскольку, как отмечает Э. Саид, «каждая эпоха и каждое общество воссоздают своих “Других” [Саид 2016, с. 514]. «Восток» как миф имеет косвенное отношение к восточным странам, он - феномен породившей его культуры.

\section{Эпоха формирования евразийского пространства}

Наиболее массированное вторжение «Востока» в пространство русской культуры было связано с включением русских княжеств в империю, созданную татаромонголами. В творчестве евразийцев Г.В. Вернадского и Л.Н. Гумилева акцент в осмыслении той эпохи сдвигается на синтетический характер российской цивилизации, имеющей глубокие восточные корни [Вернадский 1997; Гумилев 1997]. Как отмечает С.А. Нефедов, после завоевания Китая монголами «начался процесс социального синтеза и создания Монгольской империи - государства, совместившего монгольское оружие и китайские управленческие и культурные традиции. В ходе дальнейших завоеваний эта синтезированная культура распространилась на обширные пространства Азии и Европы, в том числе и на Россию» [Нефедов 2010, с. 146]. В рамках этого социокультурного синтеза при посредничестве татаро-монголов в русские земли проникла административная система китайского образца, были привнесены многие элементы материальной культуры: чугунное литье, порох, плуг китайского образца, валенки, шапка-ушанка, белила и румяна для лица, шубы, церковные купола в форме «луковиц», общественные бани, монгольские луки, бердыши (ставшие главным вооружением стрельцов), персидские доспехи, сеть почтового сообщения. Культурная диффузия с Востока отразилась и в пришедших оттуда словах, без которых уже трудно представить русский язык: базар, товар, таможня, амбар, кирпич, телега, ковер, утюг, карандаш, колбаса и другие [Нефедов 2010]. Однако татары были далеки от планов культурной ассимиляции русских, оставив в неприкосновенности их религию и бытовой уклад.

\section{Формирование мифа о «Востоке»}

C конца XVIII в. началось возвращение «Востока» в Россию, но теперь уже в виде мифа, волнующего интеллектуалов. Восточные мотивы в течение целого столетия прочно пронизывали русскую литературу, вдохновляя формирование ориен- 
талистских исследований. «Восток» пропускался через призму русской культуры, и произошло то, что Саид назвал «одомашниванием экзотики» [Cauд 2016, с. 95].

Однако парадокс состоял в том, что мода на «Восток» пришла в Россию из Западной Европы, где «значительное число крупнейших писателей XIX века были восторженными поклонниками Востока» [Саид 2016, с. 83]. Коран был переведен на русский не с арабского, а с французского языка; помимо этого, на рубеже XVIII-XIX вв. появились переводы классической персидской поэзии (зачастую с европейских языков). Многие этнографические и общекультурные сведения о восточной культуре также проникали в Россию опосредованно - через Запад (см. [Смирнов, Чалисова 2000]). Напрямую миф о «Востоке» попадал в Россию вследствие войн, которые она вела на Кавказе, Закавказье и Балканах, однако его восприятие шло под существеным влиянием западного романтизма. В конце XIX - начале XX вв. были опубликованы новые переводы персидских поэтов, в том числе и с оригинала, усиливая восточные мотивы в интеллектуальной жизни России. Помимо этого, Н. Гумилев, В. Хлебников, С. Есенин стремились подкрепить этот миф силой личных впечатлений [Белоусов 2010].

Экспансия России на Дальнем Востоке превратила ее в соседа Китая, Монголии, Японии и Кореи, и благодаря восточным мигрантам, поселившимся в том регионе, русские крестьяне осваивали навыки ведения хозяйства в непривычной для них природно-климатической зоне [Хан, Син 2014, с. 54]. В городской жизни также произошли изменения: во Владивостоке к началу ХХ в. возникли корейский, китайский и японские кварталы. В среде русской интеллигенции конца XIX - начала XX вв. появилось увлечение разными элементами культуры Дальнего Востока, среди которых можно назвать теософию Елены Блаватской (1831-1891) (см. [Андреев 2008; Крэнстон 1996; Сенкевич 1999]); духовными продолжателями ее дела стали Николай и Елена Рерихи.

На рубеже XIX-XX вв. в России начал формироваться интерес к Японии, усилившийся после поражения русской армии в войне 1904-1905 гг. Одним из привлекательных элементов японской культуры оказались приемы рукопашного боя самураев, и в начале XX в. занятия джиу-джитсу попали в обязательный перечень при подготовке сотрудников жандармского корпуса России. В 1905 г. была издана первая книга по джиу-джитсу ${ }^{2}$, потом появилась целая серия подобных изданий, переведенных по большей части с европейских языков или их адаптации. Таким образом, на примере маршрута проникновения джиу-джитсу в Россию отчетливо прорисовывается путь истернизации, идущей через Запад.

\section{Советский период}

В советскую эпоху истернизация русской повседневности в существенной мере определялась политическими и идеологическими факторами. С одной стороны, пролетарский интернационализм был провозглашен официальной доктриной, предполагавшей открытость страны культуре трудящихся классов всего мира,

2 «Джю-джицу. Система физического развития и атлетики у японцев» (перевод с французского) [Ханкок 2017]. 
a с другой, политика осажденной крепости на практике порождала жесткое регулирование границ и подозрительное отношение ко всему чужому.

Увлечение джиу-джитсу, прерванное революцией 1917 г., возобновилось в 1920-е - начале 1930-х гг., когда искусство японских самураев распространилось прежде всего среди сотрудников спецслужб и военных, тогда же джиу-джитсу стало доступно и для широкой публики, трансформировавшись в 1930-е гг. в боевое самбо ${ }^{3}$ - яркий пример советской глокализации.

В 1950-е - начале 1960-х гг. в СССР массированно насаждалась дружба с китайским народом, ее гимном стала часто звучавшая песня «Русский с китайцем братья навек». В каждом доме транслировались короткие передачи китайского радио на русском языке; распространялся журнал «Китай»; на экранах появлялись китайские фильмы (в основном на тему войны и революции); в некоторых школах вводилось преподавание китайского языка, однако с началом советско-китайского конфликта 1960-1980-х гг. проникновение китайской культуры в СССР было сведено к минимуму.

Появление в значительном количестве риса из стран Азии несколько изменило массовую русскую кухню, что стимулировало в 1980-е гг. выращивание этого злака в Краснодарском крае. Другие товары проникали бессистемно и не меняли сколько-нибудь существенно образ жизни (например, китайские термосы и декоративные подушки на рубеже 1950-1960-х гг., пляжная обувь из Вьетнама, получившая соответствующее название, - «вьетнамки»). Эксклюзивной экзотикой стали рестораны «Пекин» и «Сакура». Советский Восток проявлялся в основном в ограниченном заимствовании восточной кухни: особой популярностью пользовались шашлыки - блюдо традиционной кухни, главными проводниками которого были кавказцы, однако постепенно произошла коренизация этого блюда.

В рамках политики формирования так называемого «многонационального советского народа» государство содействовало распространению по всей территории СССР культуры союзных республик. И хотя жизнь большинства произведений была ограничена сценой официальных мероприятий, творчество представителей восточных республик (например, грузинское кино) было признано широкой общественностью и в России. Во второй половине 1960-х гг. в СССР возник культурный феномен «истерна» - приключенческого фильма, посвященного событиям преимущественно Гражданской войны в Средней Азии и на Кавказе. Следует напомнить, что истоки этого жанра восходят к фильму В.И. Пудовкина «Потомок Чингисхана» (1928 г.). В этих кинолентах заимствованная стилистика американских вестернов использовалась в целях романтизации революционной борьбы в регионах советского Востока. Впечатляющим примером мифа о Средней Азии стала чрезвычайно популярная кинокартина «Белое солнце пустыни» (1970 г., режиссер - В. Мотыль), повествующий о приключениях русского красноармейца в азиатских песках, а фраза «Восток - дело тонкое» превратилась в крылатое выражение, в котором закодировано отношение русских к «Востоку» как к чему-то, плохо поддающемуся пониманию.

\footnotetext{
3 В.С. Ощепков (1892-1937), изучавший в Японии дзюдо, добившийся высоких результатов (второй дан) и основавший во Владивостоке первую в России секцию дзюдо, исследовал выросшее из джиу-джитсу дзюдо в совокупности с иными видами борьбы и создал в середине 1930-х гг. самбо, в которой во многом под давлением идеологических соображений (Япония была враждебной страной) маскировались ее восточные корни.
} 
В 1960-е гг. в СССР возобновился интерес к восточным единоборствам: на широкие слои молодежи вдохновляющее впечатление произвел японский фильм «Гений дзюдо» (сценарий Амира Куросава, ремейк 1965 г., режиссер - С. Утикава), где, помимо дзюдо, небольшими, весьма эпизодическими врезками показаны приемы карате (или каратэ), тщательно отобранные советской цензурой. Это событие совпало с включением дзюдо в программу Олимпийских игр, что позволило под патронажем Спорткомитета СССР начать продвижение дзюдо параллельно с традиционным для советского спорта самбо. В 1970-1980-е гг. с Запада контрабандой начали привозить учебники по восточным единоборствам, среди которых особенно популярными стали книги о карате. Несмотря на мощное противодействие авторитарного государства, подпольно функционировало большое количество секций, где самостоятельно изучали этот вид единоборств. В условиях международной изоляции формировалось национальное «советское карате» - своеобразный продукт очистки оригинальных стилей от присущих им философских и этических принципов. В гораздо меньших масштабах распространилось китайское У-шу (кунг-фу).

С созданием в 1978 г. Федерации карате СССР этот вид спорта все же был временно легализован ${ }^{4}$, хотя необходимо оговориться, что организацию групп карате разрешили лишь в нескольких городах 5 . По данным Госкомспорта, в начале 1980-х гг. только в официально зарегистрированных секциях занимались свыше 300 тыс. чел., и их число продолжало расти. Но уже в 1983 г. карате снова запретили, а в Уголовный кодекс была внесена статья (ст. 219, ч. 1), предусматривающая уголовную ответственность за преподавание этого «идеологически вредного» вида спорта. Под запретом оказались и другие восточные единоборства (исключая дзюдо), однако воспрепятствовать их популярности было уже невозможно: секции в который раз ушли в подполье, маскируясь под «группы здоровья». Кроме того, получили распространение ассоциации рукопашного боя, где под патриотической оболочкой практика карате очищалась от его исходных духовных основ.

Корейское тхэквондо (синтез карате и корейских национальных видов борьбы) также попало под запрет, снятый, как и в случае с карате, лишь в 1988 г. [Цой 2016]. В 1989 г. в СССР были приглашены первые специалисты из Северной Кореи, в том же году советская сборная приняла участие в международном турнире в Пхеньяне. После нормализации отношений с Южной Кореей оттуда начали приезжать специалисты, которые, в частности, провели в 1990 г. в Ульяновске первый в СССР семинар по тхэквондо, где приняли участие 500 чел. из разных советских республик. Также была создана Федерация тхэквондо СССР; в том же году советская делегация посетила Сеул и подала заявление о вступлении во Всемирную федерацию тхэквондо [История развития тхэквондо в России б/г].

$\mathrm{B}$ поздний советский период возник интерес к японской культуре в целом: стали появляться переводы произведений классической и современной японской литературы; к составной части этого процесса также можно отнести повышенное внимание в СССР и на Западе к дзэн-буддизму, который причудливым образом выражал дух того времени. Как сказал Е. Штейнер, «это была питательная среда

\footnotetext{
4 http://ruswkf.ru

5 В 1979 г. был проведен первый чемпионат Москвы, вызвавший огромный ажиотаж.
} 
для взращивания собственной обоченности, желания быть в стороне, как можно дальше во времени и пространстве от так называемого “совка”» [Штейнер 2006]. Примечательно, что японская культура в существенной мере проникала в СССР через Запад в виде переводных с английского книг.

Эту же потребность в эскапизме обеспечивало и увлечение хатха-йогой, получившее распространение в СССР в начале 1960 -х гг. Информация о таинственной йоге просачивалась к нам очень осторожно и в основном благодаря энтузиазму первооткрывателей: один из пропагандистов йоги А.Н. Зубков ${ }^{6}$, советский и российский лингвист, находясь в долгосрочной командировке в Индии, получил сертификат, дававший ему право преподавания йоги, и, вернувшись на родину, сделал очень много для ее популяризации. В это время на русский язык с английского были переведены книги, которые тиражировались самиздатовскими методами; в больших городах страны создавались нелегальные группы йоги 7 В 1964 г. индийское посольство в Москве начало издавать журнал «Индия», в котором регулярно публиковались уроки хатха-йоги, копировавшиеся и распространявшиеся среди растущего числа ее поклонников. Однако йога, в оригинале представляющая собой систему образа жизни с мощным философским ядром, в СССР превратилась в обыкновенную экзотическую гимнастику.

Присутствие корейской культуры в советской жизни было фактически незаметно, правда, желающие могли выписывать северокорейские журналы «Корея» и «Корея сегодня»; культура же Южной Кореи вообще оставалась закрытой темой. В 1960-1980-е гг. советские корейцы, некогда высланные сталинским режимом с Дальнего Востока, стали селиться в разных частях страны, однако их культура была ограничена рамками семейной жизни.

\section{Постсоветский поворот к глобализации и рынку}

В постсоветский период истернизация повседневности шла по нескольким направлениям.

1. Рыночные реформы открыли возможности для активизации малого бизнеса мигрантов из Центральной Азии и Закавказья, и одним из наиболее доступных для них полем деятельности стала сфера торговли и общественного питания, что оказало заметное влияние на проникновение в российскую повседневность элементов азиатской кухни. В этот же процесс вписались корейцы, которые мигрировали в Россию из Центральной Азии и благодаря которым через городские рынки «морковь по-корейски» вошла в повседневное меню россиян.

2. В 1990-е гг. началось активное проникновение в российские города (сначала исключительно в крупные) восточной кухни из дальнего зарубежья. Следует отметить, что именно питание является областью, в которой глобализация идет особенно активно в форме как вестернизации [Pingali 2007], так и истернизации. В западных странах восточная кухня уже давно вошла в повседневную жизнь

\footnotetext{
6 Анатолий Николаевич Зубков - специалист по хинди, первый дипломированный йог высшей квалификации в Советском Союзе, популяризатор и пропагандист хатха-йоги.

7 Хотя официально йога была запрещена, но жестко она не преследовалась.
} 
благодаря мигрантами с Востока [Ku 2014; Yee 2012; Roberts 2000]. В постсоветский период этот процесс развернулся и в России, где первоначально восточная кухня имела статус экзотики, но постепенно превратилась в атрибут городской жизни.

Маршруты проникновения были различны: китайская кухня начала появляться вместе с китайскими мигрантами, которые находили в российских городах, как и во многих иных регионах мира, наиболее незаполненную нишу именно в сфере ресторанов и кафе с демократичными ценами. В 2017 г. только в Санкт-Петербурге функционировали более 100 заведений китайской кухни [Веселов, Цзин 2016; Веселов, Цзин 2017]. В дальнейшем динамизм этому процессу придал рост потока китайских туристов и студентов.

Совершенно иной путь проникновения оказался у японской кухни, которая появилась в России в 1990-е гг. с открытием дорогих ресторанов: в 1996 г. в гостинице «Редиссон САС Славянская» начал работу ресторан «Сумосан», чуть позже - «Саппоро» и «Токио» [История суши 2012]. На Западе в начале 1980-х гг. суши-бары были адаптированы, с одной стороны, под вкусы европейских и американских потребителей, с другой, под логику организации фаст-фуда, и именно в таком виде через Запад эта разновидность кухни страны восходящего солнца, ставшей глобальной, проникла в Россию под вывесками престижных кафе и ресторанов средней ценовой категории. В 2001 г. в Санкт-Петербурге открылась сеть «Евразия»; в 2014 г. эти рестораны только в Санкт-Петербурге посетили более одного миллиона человек. Следующим этапом стала популяризация суши и роллов вместе с сопутствующими им атрибутами в розничной торговле, причем в 2000-е гг. они утратили статус экзотики, превратившись в обычную пищу для специальных случаев.

Заметной вехой в истернизации русской повседневности в постсоветский период представляется появление в России в 1990-е гг. восточного фастфуда (или точнее, street food) в виде шавермы (московское название, или шаурмы в СанктПетербурге $)^{9}$, которая стала распространенной специализацией этнического малого бизнеса [Павлов 2006]. Это блюдо мусульманской кухни, где свинина табуирована, в европейском, а затем и в русском контексте подверглось определенной трансформации и в настоящее время нередко изготавливается с использованием запрещенного для мусульман вида мяса.

Периферийное, но все же заметное место на рынке общественного питания (в основном крупных городов) занимает также кухня других народов Азии - корейцев и тайцев.

3. Импорт потребительских товаров в Россию из азиатских стран дальнего зарубежья в существенной мере изменил материальные условия жизни россиян:

a) с конца 1980-х гг. начала приобретать крупные масштабы челночная торговля, и хотя закупки осуществлялись во многих странах, среди них, безусловно, лидировали Китай и Турция. Челночную торговлю можно причислить к одной из форм сугубо экономической истернизации, так как почти все товары были произведены по западным образцам и соответствовали западной моде;

\footnotetext{
8 В настоящее время по всей России насчитывается более 100 ресторанов сети «Евразия».

9 Это ближневосточное (либо левантийское, либо турецкое) блюдо из питы или лаваша с мясной начинкой. В Западной Европе такое блюдо давно уже получило распространение под разными названиями, происходящими от турецкого döner kebab.
} 
б) к середине 1990-х гг. в России начал формироваться массовый платежеспособный спрос на подержанные иностранные автомобили. Основными поставщиками стали Германия и Япония, которая была представлена непривычным для российских водителей автомобильным элементом - правым рулем.

4. В конце XX - начале XXI вв. на российский рынок пришли крупные азиатские импортеры из Китая, Японии и Республики Корея, открывшие в России свои представительства по продаже новой техники. Следующим этапом стало появление крупных азиатских производителей, разместивших здесь свои производства. Характерная черта этого периода заключалась в заметной роли южнокорейских фирм в глобализации российской повседневности: в жизнь широких слоев населения массово проникали средства мобильной связи, бытовая и офисная техника, косметика и автомобили из Южной Кореи.

С 2000-х гг. в России началась реализация программы привлечения в страну зарубежных автопроизводителей (Kia, Hyundai, Toyota, Volkswagen, Ford, Renault и других), которым в обмен на локализацию производства предоставлялись таможенные льготы. В 2005 г. было подписано соглашение с Toyota Motors Company о строительстве завода в Санкт-Петербурге (первые машины сошли с конвейера двумя годами позже), в 2007 г. - с корпорацией Hyundai (выпуск автомобилей начался в 2008 г.).

С 1994 до 2015 г. количество машин в России выросло с 11,5 до 40,8 млн, а доля иномарок увеличилась с 5 до $55 \%$. Важную роль в процессе автомобилизации России сыграли восточные бренды: в 2015 г. в общероссийском автопарке японские автомобили составили $39,5 \%$ всех иномарок страны, европейские - около $30 \%$, корейские - более $15 \%$, американские - $13 \%$ [Чупров 2015].

5. В 1990-е гг. были сняты административные запреты выезда за рубеж, однако очень низкий уровень доходов россиян блокировал зарубежный туризм столь же эффективно, как и ограничения советской эпохи. Все же со временем, начиная с 2000-х гг., выездной туризм стал массовым, причем господствующим оказалось азиатское направление: Турции ${ }^{10}$ и Египту (Синайскому полуострову) отдавали предпочтение жители европейских регионов России, а морские курорты Тайланда, Китая и Вьетнама ${ }^{11}$ оказались наиболее доступными жителям Дальнего Востока и Сибири. Что касается Южной Кореи, то с середины 2010-х гг. россияне начали чаще посещать эту азиатскую страну благодаря взаимной отмене визового контроля.

6. В российской молодежной среде выросло число последователей южнокорейской и японской художественной культуры: сформировались многочисленные автономные дискурсивные сообщества, также появились клубы любителей японских мультфильмов и южнокорейской анимации и художественного кино.

Особое место в процессе истернизации занимает «корейская волна» («Халлю»). Этим термином, вошедший в обиход в Китае в середине 1990-х гг., обозначается широкое распространение корейской (в основном массовой) культуры по всему миру, но прежде всего в странах Азии. Секрет успеха этого явления видится в сочетании высокого качества художественной продукции (фильмов, музыки)

10 В 2017 г. Турция стала абсолютным лидером в туристическом рейтинге России.

11 http://www.russiatourism.ru 
при относительно низких (по сравнению с западными) ценах на нее [Сэлмон 2010; Полосина 2012].

7. С 1990-х гг. восточные единоборства приобрели статус официальных видов спорта: массово создавались клубы (одно из ведущих мест заняли корейские стили, почти отсутствовавшие в советский период), тиражировались пособия по йоге, продвигались сайты, посвященные здоровому образу жизни в странах Азии.

\section{Заключение}

Основным содержанием истернизации является проникновение в русскую повседневную культуру в тех или иных масштабах культурных объектов из стран так называемого «Востока», представляющего собой социальный конструкт русского общественного сознания.

Очевидно, что истернизация выступает в качестве вектора, обратного вестернизации, однако их различие состоит не только в географической траектории культурных объектов, но и в качественном своеобразии этих процессов. Если вестернизация на разных этапах истории включала в себя заимствование культурных объектов, порождающих системную трансформацию всего образа жизни (например, автомобилизация, пригородный образ жизни), то истернизация не имеет таких глубоких и масштабных последствий. Можно предположить, что причина заключается в принципиальном различии истернизации и вестернизации. Восточные культуры, проникавшие в Россию, обладают системной уникальностью, в которой материальные практики опираются на формировавшееся веками мировоззрение. И поскольку импорт всей системы невозможен, в Россию попадают только ее отдельные элементы, вырываемые из общекультурного контекста. Совершенно иной характер имеет вестернизация повседневности, продвигаемая универсальным стремлением людей к большему физическому и духовному комфорту, при этом вместе с вещами привносятся и культурные коды общества потребления.

$\mathrm{C}$ «Востока» в русскую культуру на разных этапах ее истории проникали изолированные объекты, интегрируемые в локальную жизнь сначала в качестве экзотики, которая постепенно превращалась в ее органическую часть. Эти элементы не порождали системных трансформаций образа жизни, а ассимилировались русской повседневной культурой. Помимо этого, многие культурные объекты, пришедшие в Россию с «Востока», по своей сути оказывались продуктами западной цивилизации, ранее усвоенными народами восточных стран в процессе догоняющей модернизации.

\section{Литература}

Аксенов В. (2004) Вестерны и истерны // Огонек. № 38. С. 25.

Андреев А.И. (2008) Гималайское братство. Теософский миф и его творцы. СПб: СанктПетербургский университет.

Бек У. (2001) Что такое глобализация? М.: Прогресс-Традиция. 
Белоусов В.Г. (2010) Персидские мотивы // Esenin.ru. 7 декабря 2010 // http://www.esenin.ru/o-esenine/stati/belousov-v-g-persidskie-motivy

Вернадский Г.В. (1997) Монголы и Русь. М.: Аграф; Тверь: ЛЕАН.

Веселов Ю.В., Цзинь Ц. (2016) Процессы глобализации питания: взаимное влияние культур Запада и Востока // Здоровье и образование в XXI веке. № 9. С.135-141.

Веселов Ю.В., Цзинь Ц. (2017) Санкт-Петербург в зеркале сравнительной социологии питания // Экономическая культура мегаполиса. Альманах Центра исследований экономической культуры факультета свободных искусств и наук СПбГУ. М.-СПб.: Издательство Института Гайдара. С. 246-268.

Восток (б/г)//Толковый словарь Ушакова//http://ushakovdictionary.ru/word.php?wordid=6742 Гумилев Л.Н. (1997) Древняя Русь и Великая Степь: В 2 кн. Кн.1. М.: ДИ-ДИК.

Джиу-джитсу (б/г) // Федерация джиу-джитсу (Россия) // http://fjjr.ru/

История развития тхэквондо в России (б/г) // Союз тхэквондо России // http://tkdrussia.ru/thekvondo_dna/istoriya_razvitiya_thekvondo_v_rossii/istoriya razvitiya_thekvondo_v_rossii

История суши в России (2012) // Tabloid40.ru. 3 марта 2012 // http://tabloid40.ru/food/culinary-trends/523-istorija-sushi-v-rossii.html

Лукашев М. (1997) Сотворение самбо: родиться в царской тюрьме и умереть в сталинской. М.: Будо-Спорт.

Крэнстон С. (1996) Е.П. Блаватская: Жизнь и творчество основательницы современного теософского движения. Рига: Лигатма; М.: Сирин.

Назмутдинов Б.В. (2015) Евразийство, «Восток» и «Азия»: «восточные» устремления в трудах евразийцев (часть 1) // Socio Time. Социальное время. № 4. С. 129-140.

Назмутдинов Б.В. (2016) Евразийство, «Восток» и «Азия»: «восточные» устремления в трудах евразийцев (часть 2) // Socio Time. Социальное время. № 2. С. 118-126.

Нефедов С.А. (2010) История России. Факторный анализ. Т. І. М.: Территория будущего.

Ощепков Василий Сергеевич (б/г) // Энциклопедия «Кругосвет» // http://www.krugosvet.ru/enc/sport/OSHCHEPKOV_VASILI_SERGEEVICH.html

Павлов В. (2006) Ходовая кухня // Коммерсанть. 6 февраля 2006 // http://kommersant.ru/doc/646806

Полосина Е.В. (2012) «Корейская волна» в стратегии национального брендинга Южной Кореи // Тангалычева Р.К., Коргун И.А. (ред.) Межкультурные взаимодействия в условиях глобализации: опыт России и Кореи. Сборник статей. СПб.: Скифия-принт. C. $435-440$.

Саид Э. (2003) Восток путешественников и ученых: между словарной дефиницией и живой мыслью // Отечественные записки. № 5 // http://magazines.russ.ru/oz/2003/5/2003 5_14.html

Саид Э.В. (2016) Ориентализм. Западные концепции Востока. СПб.: Русский Мір $\overline{\text {. }}$

Сенкевич А.Н. (1999) Елена Блаватская. М.: АСТ.

Смирнов А., Чалисова Н. (2000) Подражания восточным стихотворцам: встреча русской поэзии и арабо-персидской поэтики // Сравнительная философия. М.: Восточная литература. С. 245-344.

Согомонов А.Ю. (2001) Глокальность: очерк социологии пространственного воображения // Кухтерин С.Е., Согомонов А.Ю. (ред.) Глобализация и постсоветское общество. М.: Стови. С. 60-80.

Сэлмон Э. (2010) «Халлю». Кумиры корейской поп-культуры // Пак Ы.Г., Пак Ч.С. (ред.) Корея: через тернии к звездам. 1950-2010. 60 удивительных историй корейского чуда. Сеул: Корейский институт государственного управления. С. 508-516.

Рерих Н.К. (2001) Семь великих тайн космоса. М.: Эксмо.

Хан В.С., Сим Хон Ёнг (2014) Корейцы Центральной Азии: прошлое и настоящее. M.: MBA.

Ханкок Г.И. (2017) Джиу-джитсу: система физического развития и атлетики у японцев. M.: URSS Либроком.

Хантингтон С. (2003) Столкновение цивилизаций. М.: АСТ.

Цой С. (2016) Удивительная история каратэ: от запрета до Олимпийских игр-2020 // Московский комсомолец. 4 декабря 2016 // http://www.mk.ru/sport/2016/12/04/ udivitelnaya-istoriya-karate-ot-zapreta-do-olimpiyskikh-igr2020.html 
Чупров А. (2015) Иномарки захватили дороги России // За рулем. 22 апреля 2015 // http://www.zr.ru/content/articles/779343-inomarki-zaxvatili-rossijskie-dorogi/\#

Штейнер Е. (2006) Япония и «японщина» в России и на Западе // Полит.ру 18 января 2006 // http://www.polit.ru/lectures/2006/01/18/schteiner.html

Aw B.-Y., Hwang A.R. (1995) Productivity and the Export Market: A Firm-Level Analysis // Journal of Development Economics, vol. 47, no 2, pp. 313-332.

Borup J. (2015) Easternization of the East? Zen and Spirituality as Distinct Cultural Narratives in Japan // Journal of Global Buddhism, vol. 16 // http://www.globalbuddhism.org/jgb/index.php/jgb/article/view/143

Campbell C. (2007) The Easternization of the West: A Thematic Account of Cultural Change in the Modern Era, Boulder: Paradigm Publishers.

Campbell C. (2012) Easternization // The Wiley-Blackwell Encyclopedia of Globalization, February 29,2012//http://onlinelibrary.wiley.com/doi/10.1002/9780470670590.wbeog160/ abstract;jsessionid=61EC9F7C89A849EFAF2FE4D76D3F5C3F.f02t03?userIsAuthenticat ed $=$ false $\&$ deniedAccessCustomisedMessage $=$

Easternization (Religious Movement) (n/y) // What-when-how.com // http://what-when-how.com/religious-movements/easternization-religious-movement/

Farrar L. (2010) 'Korean Wave' of Pop Culture Sweeps Across Asia // CNN, December 31, 2010 // http://edition.cnn.com/2010/WORLD/asiapcf/12/31/korea.entertainment/index.html?iref=NS1

Hussin N. (2006) The Easternization of the West: Europe Meets Asia, Bangi, Malaysia: IKON Publications.

Hwang H., Mai C.C. (1995) Strategic Management under Duopoly // Managerial and Decision Economics, vol. 16, no 3, pp. 239-247.

Kaplinsky R., Posthuma A. (2013) Easternization - The Spread of Japanese Management Techniques to Developing Countries, Routledge.

Ku R.J.-S. (2014) Dubious Gastronomy: The Cultural Politics of Eating Asian in the USA, Honolulu: University of Hawaii Press.

Mahbubani K. (2009) The New Asian Hemisphere: The Irresistible Shift of Global Power to the East, N.Y.: Public Affairs.

Nair-Venugopal S. (2012) The Gaze of the West and Framings of the East, Springer.

Pingali P. (2007) Westernization of Asian Diets and the Transformation of Food Systems: Implications for Research and Policy // Food Policy, vol. 32, no 3, pp. 281-298.

Rachman G. (2007) Easternisation. War and Peace in the Asian Century, London: The Bodley Head.

Rachman G. (2017) Easternization: Asia's Rise and America's Decline from Obama to Trump and Beyond, Other Press.

Roberts J.A.G. (2000) China to Chinatown: Chinese Food in the West, London: Reaktion Books.

Robertson R. (1994) Globalisation or Glocalisation? // Journal of International Communication, vol. 1 , no 1 , pp. 33-52.

Said E.W. (2014) Orientalism, N.Y.: Vintage Books.

Smith A. D. (1990) Towards a Global Culture? // Theory, Culture \& Society, vol. 7, no 2-3, pp. 171-191.

Voegelin E. (1997) History of Political Ideas. Vol. I. Hellenism, Rome and Early Christianity, Columbia: University of Missouri Press.

Westernization: Southeast Asia (n/y) // Encyclopedia.com // https://www.encyclopedia.com/ places/britain-ireland-france-and-low-countries/british-and-irish-political-geography-14

Yee A. (2012) Shopping at Giant Foods: Chinese American Supermarkets in Northern California, Seattle, London: University of Washington Press. 


\title{
The Easternization of Russian Everyday Life: History and Modern Times
}

\author{
V. ILYIN*
}

\begin{abstract}
*Vladimir Ilyin - DSc in Sociology, Professor, Saint-Petersburg State University; Associated Researcher, Sociological Institute of the Russian Academy of Science. Address: 1/3, Smolnogo St., Saint-Petersburg, 191124, Russian Federation. E-mail: ivi-2002@yandex.ru
\end{abstract}

Citation: Ilyin V. (2019) The Easternization of Russian Everyday Life: History and Modern Times. Mir Rossii, vol. 28, no 2, pp. 25-41 (in Russian). DOI: 10.17323/1811-038X-2019-28-2-25-41

\begin{abstract}
For centuries the process of cultural diffusion in everyday Russian culture took the forms of Westernization and Easternization. Westernization dominated all stages of Russian history, including the modern epoch. At the same time, Easternization often took paradoxical forms of Westernization: 1) The Eastern influence was often exerted on Russian everyday culture through Western countries; 2) many goods imported from the East were designed by Western firms.

Unlike Westernization, the Easternization of everyday life usually did not provoke changes in lifestyle structures because the items and practices imported from Eastern countries were isolated elements excluded from the cultural system, while the Westernization of everyday life is based on meeting the natural universal needs for physical and spiritual comfort. Because of this, it is easily hybridized with any culture, generating a kind of glocal hybrid.

The East came to Russia in two completely different forms. It directly penetrated Russian everyday life (from the invasion to the import of goods) as well as penetrated it in the form of myth. The two hypostases are partially intertwined because myth as a tool of soft power stimulates imports. This article conceptualizes the Easternization of the Russian daily life as a crosscutting process of Russian history.
\end{abstract}

Key words: Americanization, glocalization, Westernization, Easternization, Orientalism, everyday life, myth, identity

\section{References}

Aksenov V. (2004) Vesterny i isterny [Westerns and Easterns]. Ogonek, no 38, p. 25.

Andreev A.I. (2008) Gimalajskoe bratstvo. Teosofskij mif i ego tvortsy [Himalayan Brotherhood. Theosophical Myth and its Creators], Saint Petersburg: Saint-Peterburgskij universitet.

Aw B.-Y., Hwang A.R. (1995) Productivity and the Export Market: A Firm-Level Analysis. Journal of Development Economics, vol. 47, no 2, pp. 313-332. 
BeckU.(2001) Chto takoe globalizatsiya? [What Is Globalization?], Moscow: Progress-Traditsiya. Belousov V.G. (2010) Persidskie motivy [Persian Motifs]. Esenin.ru, December 7, 2010. Available at: http://www.esenin.ru/o-esenine/stati/belousov-v-g-persidskie-motivy, accessed 31.01.2019.

Borup J. (2015) Easternization of the East? Zen and Spirituality as Distinct Cultural Narratives in Japan. Journal of Global Buddhism, vol. 16. Available at: http://www.globalbuddhism.org/jgb/index.php/jgb/article/view/143, accessed 31.01.2019.

Campbell C. (2007) The Easternization of the West: A Thematic Account of Cultural Change in the Modern Era, Boulder: Paradigm Publishers.

Campbell C. (2012) Easternization. The Wiley-Blackwell Encyclopedia of Globalization, February 29, 2012. Available at: http://onlinelibrary.wiley.com/doi/10.1002/9780470670590. wbeog160/abstract;jsessionid=61EC9F7C89A849EFAF2FE4D76D3F5C3F.f02t03?userIs Authenticated $=$ false $\&$ deniedAccessCustomisedMessage $=$, accessed 31.01.2019.

Chuprov A. (2015) Inomarki zakhvatili dorogi Rossii [Foreign Cars Conquer Russian Roads]. Za rulem, April 22, 2015. Available at: http://www.zr.ru/content/articles/779343-inomarki-zaxvatili-rossijskie-dorogi/\#, accessed 31.01.2019.

Cranston S. (1996) E.P. Blavatskaya: Zhizn' i tvorchestvo osnovatel'nitsy sovremennogo teosofskogo dvizheniya [Helena Blavatsky: The Life and Works of the Founder of the Modern Theosophical Movement], Riga: Ligatma; Moscow: Sirin.

Dzhiu-dzhitsu (n/y) [Jiu-jitsu]. Federatsiya dzhiu-dzhitsu (Rossiya) [Ju-jitsu Federation (Russia)]. Available at: http://fjjr.ru/, accessed 31.01.2019.

Easternization (Religious Movement) (n/y). What-when-how.com. Available at: http://what-whenhow.com/religious-movements/easternization-religious-movement/, accessed 31.01.2019.

Farrar L. (2010) 'Korean Wave’ of Pop Culture Sweeps Across Asia. CNN, December 31, 2010. Available at: http://edition.cnn.com/2010/WORLD/asiapcf/12/31/korea.entertainment/ index.html?iref=NS, accessed 31.01.2019.

Gumilev L.N. (1997) Drevnyaya Rus' $i$ Velikaya Step'. Kn. 1 [Ancient Rus' and the Great Steppe. Book 1], Moscow: DI-DIK.

Han V.S., Sim Hon Yong (2014) Korejtsy Tsentral'noj Azii: proshloe $i$ nastoyashchee [The Koreans of the Central Asia: the Past and Modern Time], Moscow: MVA.

Hankok G.I. (2017) Dzhiu-dzhitsu: sistema fizicheskogo razvitiya i atletiki u yapontsev [Jiu-jitsu: the Japanese Athletic System], Moscow: URSS Librokom.

Huntington S. (2003) Stolknovenie tsivilizatsij [The Clash of Civilizations], Moscow: AST.

Hussin N. (2006) The Easternization of the West: Europe Meets Asia, Bangi, Malaysia: IKON Publications.

Hwang H., Mai C.C. (1995) Strategic Management under Duopoly. Managerial and Decision Economics, vol. 16, no 3, pp. 239-247.

Istoriya razvitiya thehkvondo $\mathrm{v}$ Rossii (n/y) [History of Taekwondo in Russia]. Soyuz thekhkvondo Rossii [Taekwondo Union of Russia]. Available at: http://tkdrussia.ru/thekvondo_dna/istoriya_razvitiya_thekvondo_v_rossii/istoriya_ razvitiya_thekvondo_v rossii, accessed 31.01.2019.

Istoriya sushi ${ }^{-}$v Rossii ( $\overline{2} 0 \overline{12}$ ) [History of Sushi in Russia]. Tabloid40.ru, March 3, 2012. Available at: http://tabloid40.ru/food/culinary-trends/523-istorija-sushi-v-rossii.html, accessed 31.01.2019.

Kaplinsky R., Posthuma A. (2013) Easternization - The Spread of Japanese Management Techniques to Developing Countries, Routledge.

$\mathrm{Ku}$ R.J.-S. (2014) Dubious Gastronomy: The Cultural Politics of Eating Asian in the USA, Honolulu: University of Hawaii Press.

Lukashev M. (1997) Sotvorenie sambo: rodit'sya v tsarskoj tyur'me i umeret'v stalinskoj [Creation of Sambo: To Be Born in the Royal Prison and to Die in Stalin's Prison], Moscow: Budo-Sport.

Mahbubani K. (2009) The New Asian Hemisphere: The Irresistible Shift of Global Power to the East, New York: Public Affairs.

Nair-Venugopal S. (2012) The Gaze of the West and Framings of the East, Springer.

Nazmutdinov B.V. (2015) Evrazijstvo, «Vostok» i «Aziya»: «Vostochnye» ustremleniya v trudakh evrazijtsev (Chast' 1) [Eurasianism, "Orient" and "Asia": "Eastern" Aspirations in the Writings of Eurasianists (Part 1)]. Socio Time. Sotsial'noe vremya, no 4, pp. 129-140. 
Nazmutdinov B.V. (2016) Evrazijstvo, «Vostok» i «Aziya»: «vostochnye» ustremleniya V trudakh evrazijtsev (Chast' 2) [Eurasianism, "Orient" and "Asia": "Eastern" Aspirations in the Writings of Eurasianists (Part 2)]. Socio Time. Sotsial'noe vremya, no 2, pp. 118-126.

Nefedov S.A. (2010) Istoriya Rossii. Faktornyj analiz. T. I. [History of Russia. Factor Analysis. Vol. 1], Moscow: Territoriya budushchego.

Oshchepkov Vasilij Sergeevich [Oshchepkov Vasilij]. Entsiklopediya Krugosvet [Encyclopedia "Krugosvet"]. Available at: http://www.krugosvet.ru/enc/sport/OSHCHEPKOV_VASILI_ SERGEEVICH.html, accessed 31.01.2019.

Pavlov V. (2006) Khodovaya kukhnya [Popular Kitchen]. Kommersant, February 6, 2006. Available at: http://kommersant.ru/doc/646806, accessed 31.01.2019.

Pingali P. (2007) Westernization of Asian Diets and the Transformation of Food Systems: Implications for Research and Policy. Food Policy, vol. 32, no 3, pp. 281-298.

Polosina E.V. (2012) «Korejskaya volna» v strategii natsional'nogo brendinga Yuzhnoj Korei ["Korean Wave" in the Branding Strategy of the South Korea]. Mezhkul'turnye vzaimodejstviya $v$ usloviyakh globalizatsii: opyt Rossii i Korei. Sbornik statej [Crosscultural Interaction in the Context of Globalization: the Experience of Russia and Korea. Collected Papers] (eds. Tangalycheva R.K., Korgun I.A.), Saint-Petersburg: Skifiya-print, pp. 435-440.

Rachman G. (2007) Easternisation. War and Peace in the Asian Century, London: The Bodley Head.

Rachman G. (2017) Easternization: Asia's Rise and America's Decline from Obama to Trump and Beyond, Other Press.

Roberts J.A.G. (2000) China to Chinatown: Chinese Food in the West, London: Reaktion Books.

Robertson R. (1994) Globalisation or Glocalisation? Journal of International Communication, vol. 1, no 1, pp. 33-52.

Roerich N.K. (2001) Sem'velikikh tajn kosmosa [Seven Great Secrets of Cosmos], Moscow: Eksmo.

Said E. (2003) Vostok puteshestvennikov i uchenykh: mezhdu slovarnoj definitsiej i zhivoj mysl'yu [The East of Travellers and Researchers: Between a Dictionary Definition and a Real Thought]. Otechestvennye zapiski, no 5. Available at: http://magazines.russ.ru/oz/2003/5/2003_5_14.html, accessed 31.01.2019.

Said E.W. (2014) Orientalism, New York: Vintage Books.

Said E.V. (2016) Orientalizm. Zapadnye kontseptsii Vostoka [Orientalizm. Western Concepts of the East], Saint-Petersburg: Russkij Mir.

Selmon E. (2010) «Khallyu». Kumiry korejskoj pop-kul'tury ["Hallyu”. Idols of the Korean Popculture]. Koreya: cherez ternii $k$ zvezdam. 1950-2010. 60 udivitel'nykh istorij korejskogo chuda [Korea: Through the Thorns to the Stars. 1950-2010. 60 Amazing Stories of the Korean Miracle] (eds. Pak Y.G., Pak Ch.S.), Seoul: Korejskij institut gosudarstvennogo upravleniya, pp. 508-516. Senkevich A.N. (1999) Elena Blavatskaya [Elena Blavatskaya], Moscow: AST.

Shtejner E. (2006) Yaponiya i «yaponshchina» v Rossii i na Zapade [Japan and "yaponshchina" in Russia and the West]. Polit.ru, January 18, 2006. Available at: http://www.polit.ru/lectures/2006/01/18/schteiner.html, accessed 31.01.2019.

Smirnov A., Chalisova N. (2000) Podrazhaniya vostochnym stikhotvortsam: vstrecha russkoj poezii i arabo-persidskoj poetiki [Imitations of Oriental Poets: The Encounter of Russian and Arabic-Persian Poetry]. Sravnitel'naya filosofiya [Comparative Philosophy], Moscow: Vostochnaya literatura, pp. 245-344.

Smith A. D. (1990) Towards a Global Culture? Theory, Culture \& Society, vol. 7, no 2-3, pp. 171-191.

Sogomonov A. Yu. (2001) Glokal'nost': ocherk sotsiologii prostranstvennogo voobrazheniya [Glokalization: An Essay in Sociology of Space Imagination]. Globalizatsiya i postsovetskoe obshchestvo [Globalization and post-Soviet Society] (eds. Kukhterin S.E., Sogomonov A.Yu.), Moscow: Stovi, pp. 60-80.

Tzoj S. (2016) Udivitel'naya istoriya karateh: ot zapreta do Olimpijskih igr-2020 [The Amazing History of Karate: from Prohibition to the Olympic-2020]. Moskovskij komsomolets, December 4, 2016. Available at: http://www.mk.ru/sport/2016/12/04/udivitelnaya-istoriyakarate-ot-zapreta-do-olimpiyskikh-igr2020.html, accessed 31.01.2019. 
Vernadskij G.V. (1997) Mongoly i Rus'[The Mongols and Rus'], Moscow: Agraf; Tver': LEAN.

Veselov Yu.V., Tszin' Ts. (2016) Protsessy globalizatsii pitaniya: vzaimnoe vliyanie kul'tur Zapada i Vostoka [Globalization of Food: Mutual Influence of the West and East]. Zdorov'e i obrazovanie $v$ XXI veke, no 9, pp. 135-141.

Veselov Yu.V., Tszin' Ts. (2017) Sankt-Petersburg v zerkale sravnitel'noj sotsiologii pitaniya [Saint-Petersburg in the Mirror of the Conparative Sociology of Food]. Ekonomicheskaya kul'tura megapolisa. Al'manakh Tsentra issledovanij ekonomicheskoj kul'tury fakul'teta svobodnykh iskusstv i nauk SpbGU [Economic Culture of the Metropolis. The Almanac of the Center for the Study of Economic Culture Faculty of Liberal Arts and Sciences], Moscow, Saint-Petersburg: Izdatel'stvo Instituta Gajdara, pp. 246-268.

Voegelin E. (1997) History of Political Ideas. Vol. I. Hellenism, Rome and Early Christianity, Columbia: University of Missouri Press.

Vostok (n/y). Tolkovyj slovar' Ushakova [Dictionary by Ushakov]. Available at http://ushakovdictionary.ru/word.php?wordid=6742, accessed 31.01.2019.

Westernization: Southeast Asia (n/y). Encyclopedia.com. Available at: https://www.encyclopedia.com/places/britain-ireland-france-and-low-countries/britishand-irish-political-geography-14, accessed 31.01.2019.

Yee A. (2012) Shopping at Giant Foods: Chinese American Supermarkets in Northern California, Seattle, London: University of Washington Press. 